\title{
Correction to: Geotechnical aspects and associated problems of AI-Shuaiba Lagoon soil, Red Sea Coast, Saudi Arabia
}

\author{
Bader A. Hakami ${ }^{1}$ - El-Sayed Sedek Abu Seif ${ }^{1,2}$
}

Published online: 9 March 2019

๑) Springer-Verlag GmbH Germany, part of Springer Nature 2019

\section{Correction to: Environmental Earth Sciences (2019) 78:158 https://doi.org/10.1007/s12665-019-8136-0}

In the original publication the title of the article was published wrongly as "Geotechnical aspects and associated problems of Al-Shuaiba Lagoon soil, Red Sea c, Saudi Arabia".

The correct title should be "Geotechnical aspects and associated problems of Al-Shuaiba Lagoon soil, Red Sea Coast, Saudi Arabia”.

The original article has been updated.

Publisher's Note Springer Nature remains neutral with regard to jurisdictional claims in published maps and institutional affiliations.

The original article can be found online at https://doi.org/10.1007/ s12665-019-8136-0.

El-Sayed Sedek Abu Seif

esmansor@kau.edu.sa

1 Faculty of Earth Sciences, King Abdulaziz University, Jeddah, Saudi Arabia

2 Geology Department, Faculty of Science, Sohag University, P.O. Box 82524, Sohag, Egypt 